\title{
Managing China's Coastal Environment: Using a Legal and Regulatory Perspective
}

\author{
Sheng-nan Chen and Stuart Pearson
}

\begin{abstract}
China's coastal zone is experiencing rapid population growth, increased economic development and continuing urbanization which exacerbates coastal ecosystem degradation and environmental deterioration. Integrated coastal zone management (ICZM) is adopted by the Chinese government as a promising management mechanism to alleviate the conflicts in economic growth, social stability and environmental protection, so as to achieve more sustainable coastal development. This paper, based on a PhD program on the legal and regulatory framework for ICZM, demonstrates the current legislation and institutions for coastal zone management in China and discussed their constraints in achieving ICZM. The research findings indicated that the Chinese government should manage the coastal zone as one unit with both land and waters being considered. Therefore, a national coastal law is necessary for such a vast country as China and the integration among agencies is essential for the legislation. In addition, it is not reasonable to have the State Oceanic Administration (SOA) as the leading agency for coastal zone management in China, since its jurisdiction does not involve any terrestrial land on the coastal zone.
\end{abstract}

Index Terms-Coastal environment, integrated coastal zone management (ICZM), legislation, institutions.

\section{INTRODUCTION}

Integrated coastal zone management (ICZM) has a global tradition as a part of a spring tide of integrated approaches in natural resource management [1]. Cicin-Sain \& Knecht [2] defined integrated coastal zone management (ICZM) as "a continuous and dynamic process by which decisions are made for the sustainable use, development, and protection of coastal and marine areas and resources". The "integration" in ICZM is defined as an approach to achieve sustainable coastal zone management with comprehensive consideration of social, economic and environmental values of the dynamic coastal systems [3]-[5].

The Chinese coastline is around $18,000 \mathrm{~km}$, stretching across tropical, subtropical and temperate zones [6], [7]. In China, around $60 \%$ of the people live in the 12 coastal provinces. More than $70 \%$ of large Chinese cities are located in the coastal areas and the coastal development contributes over $55 \%$ to the national gross domestic productivity (GDP) [8]. However, the rapid population growth, increased

Manuscript received May 10, 2014; revised July 10, 2014. This work was supported by the School of Physical, Environmental and Mathematical Sciences (PEMS) of the University of New South Wales (UNSW) Canberra (No. PS28170).

Sheng-nan Chen and Stuart Pearson are with the Sino-Australian Research Centre for Coastal Management (SARCCM) and School of PEMS, UNSW Canberra, ACT, Australia (e-mail: s.chen@student.adfa.edu.au, s.pearson@adfa.edu.au). economic development and continuing urbanization and infrastructure development have exacerbated coastal ecosystem degradation and environmental deterioration, threatening the sustainable coastal development in China [9], [10]. Currently the Chinese government accepts ICZM as their coastal management mechanism [1], [11], which is reflected in their legal and government documents. According to the Priority Project Plan of China's Agenda 21, integrated coastal zone management was one of the projects under the priority area of natural resource management and utilization. Also, the Chinese government has implemented integrated management at local levels, such as Xiamen, Fujian, Shanghai and Shandong [9], [12]-[17]. In 2011, the establishment of Shandong Peninsula Blue Economic Zone, Zhejiang Marine Economic Development Model Zone and Guangdong Marine Economic Development Pilot Zone all embodied the integrated management mechanism for coastal provinces [18].

In the implementation of coastal zone management, there is a growing interest in the legal and regulatory framework [19]. The World Bank defined ICZM as "a process of governance and consists of the legal and institutional framework necessary to ensure that development and management plans for coastal zones are integrated with environmental (including social) goals and are made with the participation of those affected" [20]. For the implementation of ICZM and achievement of sustainable coastal development, a more reliable and effective legal and regulatory framework has been considered essential by both social and physical science researchers [1], [3], [21], [22]. This paper is drawn from a $\mathrm{PhD}$ program which compares and evaluates the Australian and Chinese legal and regulatory frameworks related to integrated coastal zone management. In China, the authors observed the coastal management issues through lens of Shandong Peninsula Blue Economic Zone and a specific coastal development, Celebration City in Qingdao, Shandong Province. We draw on interviews, questionnaires, case inspections, publications and other data to achieve a measure of research 'triangulation'. The 26 Chinese respondents were selected from governments, academia, business, NGOs and local community. Based on the findings in the $\mathrm{PhD}$ program, this paper will demonstrate the legislation and institutions in the current legal and regulatory framework for ICZM in China. In addition, their constraints in achieving effective ICZM will be explained and discussed.

\section{LEGISLATION}

"Law exerts an inevitable influence over the process of 
integrated coastal zone management (ICZM). Even when non-statutory means are employed to achieve the objectives of ICZM, they must function within an established legal framework that already defines the powers and duties of many public and private stakeholders involved in the administration and use of coastal areas" [23].

TABLE I: MAJOR LAWS AND REGULATIONS RELATED TO COASTAL ZONE MANAGEMENT IN CHINA

\begin{tabular}{|c|c|c|}
\hline Laws/Regulations & Year & Level \\
\hline $\begin{array}{c}\text { Law on the Territorial Sea and the } \\
\text { Contiguous Zone }\end{array}$ & 1992 & National \\
\hline $\begin{array}{c}\text { Law on Exclusive Economic Zones and } \\
\text { Continental Shelves }\end{array}$ & 1998 & National \\
\hline Marine Environment Protection Law & 1982 & National \\
\hline $\begin{array}{l}\text { Law on the Administration of the Use of } \\
\text { Sea Areas }\end{array}$ & 2001 & National \\
\hline $\begin{array}{l}\text { Law on the Protection of Offshore } \\
\text { Islands }\end{array}$ & 2009 & National \\
\hline $\begin{array}{l}\text { Law on Evaluation of Environmental } \\
\qquad \text { Affects }\end{array}$ & 2002 & National \\
\hline Environmental Protection Law & 1989 & National \\
\hline Fisheries Law & 1986 & National \\
\hline Mineral Resources Law & 1986 & National \\
\hline Law on Land Resources Management & 1986 & National \\
\hline Port Law & 2003 & National \\
\hline Maritime Traffic Safety Law & 1983 & National \\
\hline Law on the Protection of Wildlife & 1989 & National \\
\hline $\begin{array}{l}\text { Regulations Concerning Prevention and } \\
\text { Control of Pollution Damages to the } \\
\text { Marine Environment by Coastal } \\
\text { Construction Projects }\end{array}$ & 1990 & National \\
\hline $\begin{array}{l}\text { Regulations Concerning Prevention and } \\
\text { Control of Pollution Damage to the } \\
\text { Marine Environment by Marine } \\
\text { Construction Projects }\end{array}$ & 2006 & National \\
\hline $\begin{array}{c}\text { Regulations Concerning Prevention of } \\
\text { Pollution Damage to the Marine } \\
\text { Environment by Land-based } \\
\text { Pollutants }\end{array}$ & 1990 & National \\
\hline $\begin{array}{l}\text { Regulations on Control of Dumping of } \\
\text { Wastes in the Ocean }\end{array}$ & 1985 & National \\
\hline $\begin{array}{l}\text { Regulations on Prevention and Control of } \\
\text { Marine Environment Pollution from } \\
\text { Ships }\end{array}$ & 2009 & National \\
\hline $\begin{array}{l}\text { Regulations on Administration of } \\
\text { Environmental Protection in the } \\
\text { Exploration and Development of } \\
\text { Offshore Petroleum }\end{array}$ & 1983 & National \\
\hline $\begin{array}{c}\text { Regulations of Natural Protected } \\
\text { Reserves }\end{array}$ & 1994 & National \\
\hline $\begin{array}{c}\text { Regulations Concerning Prevention of } \\
\text { Environmental Pollution by } \\
\text { Ship-breaking }\end{array}$ & 1988 & National \\
\hline $\begin{array}{l}\text { Implementation Regulations on } \\
\text { Protection of Aquatic Wildlife }\end{array}$ & 1993 & National \\
\hline $\begin{array}{l}\text { Regulations on Coastal Zone } \\
\text { Management of Jiangsu Province }\end{array}$ & 1992 & Provincial \\
\hline $\begin{array}{c}\text { Regulations on Coastal Zone Protection } \\
\text { and Exploitation Management of } \\
\text { Hainan Special Economic Zone }\end{array}$ & 2013 & Provincial \\
\hline $\begin{array}{l}\text { Regulations on Coastal Zone Protection } \\
\text { and Utilization of Liaoning Province }\end{array}$ & 2013 & Provincial \\
\hline $\begin{array}{c}\text { Regulations on Administration of Coastal } \\
\text { Zone Planning of Qingdao City }\end{array}$ & 1999 & Municipal \\
\hline
\end{tabular}

"Ruling the country by law" is a fundamental state strategy in China, and there are a series of laws and regulations related to marine and coastal matters at national and local levels (see in Table I) [6], [24]. These laws and regulations provide legal guidance and justification for coastal management schemes and practice.

Most government officials and academic respondents agreed that most aspects of coastal zone have been covered by the existing laws and regulations. These laws and regulations have specific or relevant provisions regulating the exploitation and protection of coastal resources and the management of human activities on the coastal zone [25]. Among them, the Marine Environment Protection Law of the PRC and Law of the PRC on the Administration of the Use of Sea Areas are two key pieces.

In China, the Marine Environment Protection Law of the $P R C$ (1982) is the most important law for marine and coastal zone management [24]. It fostered an inter-governmental mechanism in marine management and stipulated the formation of a marine functional zoning scheme, establishment of marine nature reserves and implementation of marine environmental impact assessment system. These management measures consolidate the legal basis for the practice of marine and coastal zone management [9]. The Marine Environment Protection Law of the PRC (1982) also makes provisions for the prevention and management of marine pollutions and lays foundations for a series of laws and regulations consecutively after 1982 [24]. It mainly covers five sources of pollution: pollution by dumping of wastes in the ocean, pollution by land-based pollutants, pollution from coastal construction projects, pollution from marine construction projects, and pollution by ships. Correspondingly, the State Council promulgated administrative regulations which are the first five pieces of national regulations enumerated in Table $I$. The implementation of Marine Environment Protection Law (1982) in the past decades indicates that the marine environment protection has been strengthened, the effectiveness of enforcement has been heightened, and the marine legal system has been improved, according to Keyuan [24].

In the 1990s, the annual GDP growth rate of China's marine sectors was around $20 \%$ and the sea use activities were intensified due to the local and foreign investment. These intensive sea use activities raised disorderly and excessive sea use, abuse of marine resource and deterioration of marine environment. Considering these problems, in 1993, the Tentative Regulations on Management of Sea Use was put into force, and it was further developed into the Law on the Administration of the Use of Sea Areas enacted in 2001. Internationally, the promulgation of the Law on the Administration of the Use of Sea Areas (2001) responded to the United Nations Conference on Environment and Development in 1992 which had called for ICZM to achieve sustainable development [26]. This Law contributed to the establishment of the right to the sea use authorization system, user-fee system and marine functional zoning system [27]. For coastal zone management, the Law is of great importance to the coastal water use and supervision. The promulgation and implementation of the Law improved the legal system for ICZM and a series of administrative regulations and 
regulatory documents were issued [26]. Among them, the most important is the Notice on the Assessment and Approval of Projects on Sea Use in the Coastal Provinces, Autonomous Regions and Municipalities directly under the Central Government which was issued by the State Council and set the mandate of provinces. In accordance to the Law and the Notice, the application of sea use shall be assessed and approved by the State Council, or the people's governments of provinces, autonomous regions and municipalities directly under the Central Government with the authorization of the State Council. Thus, for sea use activities, a two-level management system was established which ensured the sea use activities were under stricter control of the provincial and central governments [26]. The enforcement of the Law on the Administration of the Use of Sea Areas (2001) and the implementation of the sea use authorization, user-fee and marine functional zoning systems provided experimental experience in the coastal sea use and enhanced the legalization regarding sea use, alleviated the intensive sea use conflicts, guided the distribution of marine development and ameliorated the eco-environment.

In China, there is currently no national law or regulation specifically for coastal zone management [9], though a few such regulations exist in the coastal provinces and cities (see in Table I). With the conduct of the "Countrywide Comprehensive Investigations of the Coastal Zone and Tidal Land Resources" in 1980s, the Law on Coastal Zone Management was drafted since 1983, it was not codified and was downgraded to the Regulations on Coastal Zone Management [28], [29]. After nearly ten years of draft and revision, the Regulations was refused for two main reasons: one was that the existing laws and regulations have covered most aspects of coastal zone management and new laws or regulations would cause legislative redundancy and overlap; the other was that there were conflicts of interest among government agencies, as most agencies expected more rights but less responsibilities through the promulgation of new laws or regulations [29]-[31]. The State Development Planning Commission in the 1990s, for the exploitation and protection of coastal zone and tidal land resources, initiated the Regulations of Coastal Zone and Tidal Land Resources. The Regulations came to nothing for the same reasons as for the special coastal laws and regulations in 1980s [29]. According to Chinese academics, an essential question is not how to establish more special laws and regulations, but how to amend the current ones and make them more effective for coastal zone management. For one thing, the coastal zone cannot be well managed by a special law or regulation, since there are a large variety of coastal issues which can be affected by the surrounding territory, marine and air environment and influenced by a wide range of government agencies and coastal stakeholders. For another, it is not easy to adopt a special law and regulation to the current system of laws and regulations.

Therefore, before enacting a special law for coastal zone management, it will be important to increase the awareness of the overall situation, predict the benefits and costs of law-making and establish an integrated mechanism among government agencies that is demonstrably better than the current arrangements.

\section{INSTITUTIONS}

"Laws both shape and are shaped by, institutions" [32]. Karim \& Hoque [19] mentioned "a well-defined legal framework is a must for establishing an enabling institutional framework for ICZM". On the other hand, the existing administrative and legal institutions are of importance to the design of new legislation and the amendment of existing legislation to achieve ICZM [32] and they are the key practitioners of coastal zone management. Effective and well-functioning institutions contribute to the implementation of laws and regulations, the performance of coastal policies and programs and the achievement of integration in coastal zone management [33], [34].

TABLE II: Key MinistRIES AND AGENCIES RELATED TO COASTAL ZONE MANAGEMENT IN THE CHINESE CENTRAL GOVERNMENT

\begin{tabular}{|c|c|}
\hline Ministries/Agencies & Functions \\
\hline $\begin{array}{l}\text { Ministry of Land } \\
\text { and Resources }\end{array}$ & $\begin{array}{c}\text { Protect and rationally utilize the natural } \\
\text { resources on coasts such as land, mineral and } \\
\text { marine resources. }\end{array}$ \\
\hline $\begin{array}{l}\text { State Oceanic } \\
\text { Administration }\end{array}$ & $\begin{array}{l}\text { Draft basic marine laws, regulations and } \\
\text { policies; coordinate marine activities and } \\
\text { institutions; draft regulations and rules to } \\
\text { safeguard legal rights and enforce laws; draft } \\
\text { and supervise the marine zoning plan and sea } \\
\text { area uses; be responsible for island protection } \\
\text { and marine ecological environment protection; } \\
\text { manage the marine monitoring and surveillance, } \\
\text { and hazard forecasting and warning; manage the } \\
\text { marine technology development, marine } \\
\text { economy supervision and marine international } \\
\text { cooperation; undertake tasks related to National } \\
\text { Oceanic Administration. }\end{array}$ \\
\hline $\begin{array}{l}\text { Ministry of } \\
\text { Environmental } \\
\text { Protection }\end{array}$ & $\begin{array}{c}\text { Control coastal environmental problems from } \\
\text { human activities. }\end{array}$ \\
\hline & $\begin{array}{l}\text { Supervise waterborne traffic safety such as } \\
\text { waterborne traffic control, inspection of ships }\end{array}$ \\
\hline $\begin{array}{l}\text { Ministry of } \\
\text { Transport }\end{array}$ & $\begin{array}{l}\text { and its crews and equipments, and registration } \\
\text { and prevention of pollution; guide public } \\
\text { security related to maritime affairs, navigation } \\
\text { and harbors. }\end{array}$ \\
\hline $\begin{array}{l}\text { Ministry of Water } \\
\text { Resources }\end{array}$ & $\begin{array}{l}\text { Develop and manage water infrastructures, } \\
\text { major rivers, shorelines, estuaries and coast } \\
\text { beaches. }\end{array}$ \\
\hline $\begin{array}{l}\text { Ministry of } \\
\text { Agriculture }\end{array}$ & $\begin{array}{l}\text { Guide the exploitation and protection of fishery } \\
\text { resources in fishery waters, shoals and swamps. }\end{array}$ \\
\hline
\end{tabular}

China has traditionally a top-down or centralized approach to regulating natural resource management [6]. In China, the Central Government plays a key role in policy-making, while local governments take more responsibilities to implement coastal zone management or ICZM [9]. As for government agencies, the local departments and national ministries do not correspond one-to-one, but there are always agencies with corresponding functions in the governments of each level [6]. In the Chinese Central Government, there is no specific agency or institution taking the responsibilities of ICZM [9]. The coastal zone management is "a matter of shared responsibility involving many ministries and departments and local communities" [25] and it is basically a fragmented mechanism with integration as the key objective in the future [27], [35]. Table II, according to the website of the Central Government of China (http://english.gov.cn/links.htm\#1), lists the key ministries and agencies related to coastal zone 
management in the Chinese Central Government and summarizes their management functions. The governments at local levels have similar horizontal structure of corresponding agencies and management functions in the central government [6].

In the Chinese Central Government, the Ministry of Land and Resources is responsible for the planning, administration, protection and rational utilization of such natural resources as land, mineral and marine resources, so the coastal lands and coastal waters are both under the authority of the Ministry of Land and Resources. The State Oceanic Administration (SOA) subordinated to the Ministry of Land and Resources is the leading agency for coastal zone management [9], [36] and it is empowered to manage the marine affairs and coordinate among agencies for marine and coastal zone management [6]. The Ministry of Environmental Protection has the leading role in overall environmental management, including the cooperation with SOA on coastal waters and specifically the prevention of marine pollution from land-based sources and coastal construction projects [6], [35], [36]. Overall, there are about twenty ministries and agencies related to coastal zone management include the Ministry of Transport, Ministry of Water Resources, and Ministry of Agriculture [6]. The obligations of these agencies are not only for coasts, but they make guidance and standards related to coastal zone management [9]. Among these agencies, there is coordination and also internal competition for administrative interest on coasts [35]. In dealing with management issues, including marine and coastal issues, they usually attempt to obtain more benefits and evade responsibilities, which results in the internal competition among government agencies [29].

The coastal zone management has a great overlap with marine management in China and so the SOA, in charge of marine affairs, is widely regarded as the leading agency for coastal zone management [29], [37]. The leadership of SOA in coastal zone management was also widely accepted by the respondents from governments and academia in this research. In China, the marine management mechanism and institutional reforms generally have experienced three major stages: from the foundation of the PRC in 1949 to 1970s, 1980s to early 1990s and 1990s until now. In the first stage, the marine management developed from resource-based mechanism to institution-based mechanism, during which the SOA and its three branches were set up; the second stage can be regarded as a transition period in which the marine institutions were established at local levels; in the third stage, the marine management was gradually developing into integrated mechanism and integration is the goal of the third stage and also the future.

\section{A. Establishment of National Marine Institutions (1949 - 1970s)}

After the foundation of the People's Republic of China in 1949 , the ocean and coastal zone were managed in terms of different natural resources, so marine and coastal zone management were basically the extension of natural resource management on land [38], [39]. All the government agencies related to marine resource management reflected a resource-based sectoral mechanism. However, the rapid development of society and economy and the rising conflicts related to marine resource management rendered this sectoral mechanism inefficient [39].

In 1964, the State Oceanic Administration was established and it was entrusted to manage marine resources, conduct marine environmental survey, collect and collate marine information, and provide marine public service. The newly established SOA was expected to transfer the sectoral and temporal coordinative mechanism to a specialized and stable marine working force [29]. In 1965, the North China Sea Branch, East China Sea Branch and South China Sea Branch of SOA were set up in Qingdao, Ningbo and Guangzhou to respectively manage the Bohai Sea and Yellow Sea, East China Sea, and South China Sea and they are directly subordinated to the SOA. The establishment of the SOA and its three branches signified the initial formation of national administration for marine management and created the vertical management mechanism between the SOA and its three regional branches [38].

\section{B. Establishment of Local Marine Institutions (1980s - Early 1990s) Final Stage}

In 1978, the "reform and opening-up policy" was launched in China and after that the coastal areas benefited more from their outstanding locations and abundant natural resources. This laid a foundation for further marine institutional reforms. In 1982, the SOA was upgraded to an organization directly under the State Council [39], which reflects the national attention on marine affairs.

With the enforcement of the reform and opening-up policy and the exploitation of natural resources, the local governments were more involved in marine and coastal zone management. After the national government institutional reform in 1988 and the reform of marine management system in 1989, the local marine management agencies were gradually set up in the provincial, municipal and county governments [39]. The local marine management agencies were organized in the following forms [39]:

1) Combining marine and fishery management agencies

2) Independent marine management agencies

3) Agencies merged into land and resource management institutions

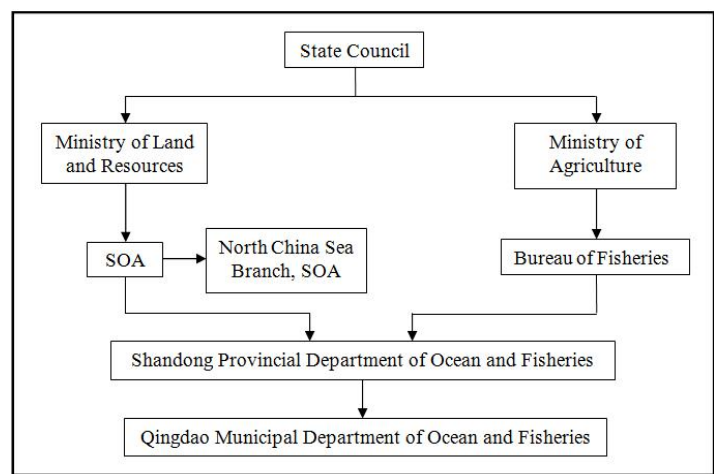

Fig. 1. The vertical/intergovernmental marine management mechanism for Qingdao City, China.

The establishment of local marine management agencies augmented the efficiency of marine management at local levels and facilitated the vertical integration among governments at different levels. Hence, China's marine administration established vertical or intergovernmental 
mechanisms among the national, provincial, municipal and county (or district) governments. Besides, in 1989, the marine management regions and marine monitoring stations were established under the three branches of SOA. Thus, the SOA has a 4-tier administrative mechanism, that is, the SOA, its three branches, marine management regions and marine monitoring stations [29]. Fig. 1, taking Qingdao City in Shandong Province as an example, illustrates the vertical/intergovernmental marine management mechanism in China.

\section{Integrated Marine Management at the Initial Stage (1990s up till Now)}

Since 1983, the State Council in China experienced re-organization of the administrative structure and responsibility every five years. Before 1993, the SOA was directly subordinated to the State Council, but after the structural reform of State Council in 1993, SOA was incorporated into the Commission of Science and Technology under the State Council. In 1998, another structural reform took place in China and since then the SOA has been under the newly established Ministry of Land and Resources as a "managed unit" [36]. Despite the downgrading and upgrading of SOA, it has been continuously entrusted with greater power [36], [39].

After 1990s, all the Chinese governments at the provincial, municipal and county levels on the coastal zone have set up marine management agencies to undertake the marine management tasks at local levels [39]. After the national government institutional reform in 2008, the SOA was entrusted a new function, that is, to strengthen the research on marine strategies and intensify the integration and cooperation on marine affairs. It is the first time for the SOA to have a function of integrated management, which clearly manifests that integrated mechanism is the objective of marine management [39]. In the latest structural reform of State Council in 2013, the SOA has been empowered to manage the newly established National Oceanic Committee and China Coast Guard. All these changes show the growing importance of SOA and marine management in China.

\section{DISCUSSION AND CONCLUSION}

Many previous publications have provided discussion and recommendations for more integrated coastal zone management in China, due to the lack of coordination amongst governments and government agencies, lack of stakeholder involvement, lack of capacity building and a shortage of information for effective monitoring and evaluation [6], [9], [29], [39]-[41]. According to this research, another important recommendation could be to manage the coastal zone in China as one unit with both land and waters being considered; therefore, more comprehensive legislation and institutions covering both coastal land and waters are necessary for achieving ICZM.

Currently, China has no national law or institution specifically for coastal zone management with consideration of both coastal land and waters and regulating the cross-jurisdictional coastal issues, even though the coastal zone in China is experiencing the most pressure from economic development and population growth. In China, coastal zone management is generally regarded as a part of marine management [29]. As demonstrated in the sections about legislation and institutions, the key pieces of legislation and leading agency for coastal zone management in China mainly specializes in marine issues. The Marine Environment Protection Law of the PRC (1982) and Law on the Administration of the Use of Sea Areas (2001) were initially promulgated to improve the marine environment and to establish an authorization system for sea use. They can only be applied to the coastal waters on the coastal zone. It is also not reasonable to have the SOA, which only has jurisdiction on marine management, to be the leading agency on coastal zone management in China. The failure to promulgate the Law on Coastal Zone Management in 1980s, which was lead by the SOA, is strong evidence to show that one agency without comprehensive understanding and experience in dealing with coastal issues cannot ultimately achieve ICZM.

The coastal zone is a geographical entity covering both terrestrial and submerged areas along the coastline and it is the interface between the land and sea [3], [6], [37], [39]. It is essential to consider coastal land, coastline and coastal waters as a whole continuum, and to take an integrated approach to manage the issues on the continuum within a legal and regulatory framework [6]. Base on the current legislation and institutions in China, an integrated mechanism with a guiding legislation on coastal zone and advisory or administrative organizations coordinating amongst governments and government agencies for coastal issues is necessary. Considering the coastal zone as one unit with both land and waters is of most significance to achieve more integrated management on China's coastal zone.

\section{REFERENCES}

[1] X. Wang, X. Xu, S. Pearson, G. Xue, R. Morrison, D. Liu, and P. Shi, "Integrated coastal zone management research in Australia and China," Labour and Management in Development, vol. 11. pp. 1-17, 2011.

[2] B. Cicin-Sain and R. W. Knecht, Integrated Coastal and Ocean Management: Concepts and Practices, Washington D. C.: Island Press, 1998, p. 39.

[3] N. Harvey and B. Caton, Coastal Management in Australia, Adelaide: University of Adelaide Press, 2010, pp. 1-18.

[4] R. Kenchington and D. Crawford, "On the meaning of integration in coastal zone management," Ocean \& Coastal Management, vol. 21, no. 1-3, pp. 109-127, 1993.

[5] J. Sorensen, "The international proliferation of integrated coastal zone management efforts," Ocean \& Coastal Management, vol. 21, no. 1-3, pp. 45-80, 1993.

[6] W. Cao and M. H. Wong, "Current status of coastal zone issues and management in China: A review," Environment International, vol. 33 , no. 7, pp. 985-992, May 2007.

[7] Q. Qin, L. Zhu, A. Ghulam, Z. Li, and P. Nan, "Satellite monitoring of spatio-temperal dynamics of China's coastal zone eco-environments: Preliminary analysis on the relationship between the environment, climate change and human behaviour," Enviornmental Geology, vol. 55, no. 8, pp. 1687-1698, Oct. 2008.

[8] Y. Wang, "Coastal management in China," in International Conference on Ocean Management in Global Change, P. Fabbri, Ed. London: Elsevier Applied Science, 1992, pp. 469-479.

[9] X. Q. Wu, M. Gao, D. Wang, Y. Wang, Q. S. Lu and Z. D. Zhang, "Framework and practice of integrated coastal zone management in Shandong Province, China," Ocean \& Coastal Management, vol. 69 , pp. 58-67, Dec. 2012.

[10] X. Xue, H. Hong and A. T. Charles, "Cumulative environmental impacts and integrated coastal management: the case of Xiamen, China," Journal of Environmental Management, vol. 71, no. 3, pp 271-283, Jul. 2004. 
[11] S. Pearson, X. H. Wang, and G. Xue, "Coastal management in China and Australia: Introduction to the special edition," Labour and Management in Development Journal, vol. 11. pp. 1-3, 2011.

[12] S. Luo, H. Wang, and F. Cai, "An integrated risk assessment of coastal erosion based on fuzzy set theory along Fujian coast, southeast China," Ocean \& Coastal Management, vol. 84, pp. 68-76, Nov. 2013.

[13] B. Peng, H. Hong, X. Xue, and D. Jin, "On the measurement of socioeconomic benefits of integrated coastal management (ICM): Application to Xiamen, China," Ocean \& Coastal Management, vol. 49, no. 3-4, pp. 93-109, 2006.

[14] C. Shi, S. Hutchinson L. Yu, and S. Xu, "Towards a sustainable coast: an integrated coastal zone management framework for Shanghai, People's Republic of China," Ocean \& Coastal Management, vol. 44, no. 5-6, pp. 411-427, 2001.

[15] C. Shi, S. M. Hutchinson, and S. Xu, "Evaluation of coastal zone sustainability: An integrated approach applied in Shanghai Municipality and Chong Ming Island," Journal of Environmental Management, vol. 71, no. 4, pp. 335-344, Jul. 2004.

[16] T. E. Chua, H. Yu, and G. Q. Chen, "From sectoral to integrated coastal management: A case in Xiamen, China," Ocean \& Coastal Management, vol. 37, no. 2, pp. 233-251, 1997.

[17] G. Ye, L. M. Chou, and W. Hu, "The role of an integrated coastal management framework in the long-term restoration of Yundang Lagoon, Xiamen, China," Journal of Environmental Planning and Management, pp. 1-20, Sep. 2013.

[18] J. Q. Lv, P. P. Liu, and Y. Wei, "A quantitative analysis of regional differences in Urban-rural Integration - A case study of the Shandong Peninsula Blue Economic Zone," in Frontiers of Green Building, Materials and Civil Engineering, D. Sun, W. P. Sung, and R. Chen, Eds. Stafa-Zurich: Trans Tech Publications Ltd, 2011, vol. 71-78, pp. 4748-4755.

[19] M. S. Karim and R. Hoque, "Integrated coastal zone management and sustainable development of Coastal Area: A short overview of International Legal Framework," in Integrated Coastal Zone Management, E. Moksness, E. Dahl and J. Støttrup, Eds. Oxford: Wiley-Blackwell, 2009, ch. 13, pp. 170-179.

[20] J. C. Post and C. G. Lundin, Guidelines for Integrated Coastal Zone Management, Washington, D. C: The World Bank, 1996, p. 3.

[21] D. R. Rothwell, "The legal framework for ocean and coastal management in Australia," Ocean \& Coastal Management, vol. 33, no. 1-3, pp. 41-61, 1996.

[22] G. Wescott, "Stimulating vertical integration in coastal management in a federated nation: The case of Australian Coastal Policy Reform," Coastal management, vol. 37, no. 6, pp. 501-513, Nov. 2009.

[23] J. Gibson, "Integrated coastal zone management law in the European Union," Coastal Management, vol. 31, no. 2, pp. 127-136, Oct. 2003.

[24] Z. Keyuan, "Implementing marine environmental protection law in China: progress, problems and prospects," Marine Policy, vol. 23, no. 3, pp. 207-225, May 1999.

[25] F. Zhijie and P. P. Côté, "Coastal zone of PR China: Management approaches and institutions," Marine Policy, vol. 14, no. 4, pp. 305-314, Jul. 1990.

[26] H. Li, "The impacts and implications of the legal framework for sea use planning and management in China," Ocean \& Coastal Management, vol. 49, no. 9-10, pp. 717-726, 2006.

[27] Y. C. Chang, N. Wang, and Y. Zhao, "The current development of the ocean governance mechanism in China," Coastal Management, vol. 41, no. 2, pp. 120-133, Mar. 2013.

[28] S. J. Su, "Seven-year countrywide comprehensive investigations of the coastal zone and tidal land resources," Ocean and Coastal Zone Development, no. 2, pp. 30-32, 1988.

[29] S. B. Lu and W. Z. Ai, Integrated Coastal Zone Management Research on Institutional Arrangements and Operating Mechanisms, Beijing: China Ocean Press, 2001, pp. 127-168.

[30] K. N. Huang and S. L. Huang, "Analysis on legal issues of integrated coastal zone management in China," Guangdong Agricultural Sciences, no. 4, pp. 350-354, 2010.
[31] K. N. Huang and S. L. Huang, "An exploratory study of integrated coastal zone management in China," Journal of Shanghai Ocean University, vol. 19, no. 2, pp. 246-251, Mar. 2010.

[32] C. Cullinan, Integrated Coastal Management Law: Establishing and Strengthening National Legal Frameworks for Integrated Coastal Management, Rome: Food \& Agriculture Org, 2006, pp. 221-230.

[33] M. Haward, "Institutional framework for Australian ocean and coastal management," Ocean \& Coastal Management, vol. 33, no. 1-3, pp. 19-39, 1996

[34] M. L. Tissier, D. Roth, M. Bavinck, and L. Visser, Integrated Coastal Management: From Post-graduate to Professional Coastal Manager: A Teaching Manual, Delft: Eburon Academic Publishers, 2011, pp. 42-46.

[35] S. Chen and J. I. Uitto, "Governing marine and coastal environment in China: Building local government capacity through international cooperation," China Environment Series, no. 6, pp. 67-80, 2007.

[36] M. Lau, "Integrated coastal zone management in the People's Republic of China-An assessment of structural impacts on decision-making processes," Ocean \& Coastal Management, vol. 48, no. 2, pp. 115-159, 2005.

[37] B. Q. Li, Coastal Zone Management Research, Beijing: China Ocean Press, 2011, pp. 12-60.

[38] W. W. Zhong, "Analysis on the development of marine management mechanism in China (1949-2009)," Theory Monthly, no. 2, 2013.

[39] Research Group of Marine Development Strategy Institute in State Oceanic Administration, China' Ocean Development Report (2011), Beijing: China Ocean Press, 2011.

[40] H. Hong and X. Xue, "Building up a training base for integrated coastal management through partnerships in Xiamen," Ocean \& Coastal Management, vol. 49, no. 9-10, pp. 685-695, 2006.

[41] X. Y. Zhang and X. Z. Xue, "Evaluation indicators for Integrated Coastal Management (ICM) in China: lessons learned from Xiamen," Advanced Materials Research, vol. 356-360, pp. 840-843, 2012.

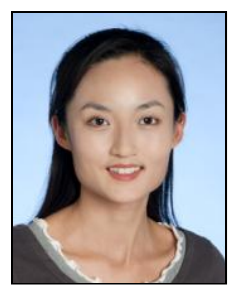

Sheng-nan Chen was born in the city of Zibo in Shandong Province in 1986, and now she is a PhD candidate in the University of New South Wales (UNSW) Canberra, Australia and majors in oceanography. Her $\mathrm{PhD}$ program is a comparative study on the legal and regulatory framework related to integrated coastal zone management between Australia and China. This PhD program is also included in the research topics of the Sino-Australian Research Center for Coastal Management (SARCCM) which is jointly established by the UNSW Canberra in Australia and the Ocean University of China (OUC) in China. Her co-authored paper entitled of "Judicial experience in environmental protection: an interview with the Chief Judge of the Land and Environment Court of New South Wales, Australia" has been published in the journal of China Environment Law Review, vol. 9, pp. 87-101, 2013.

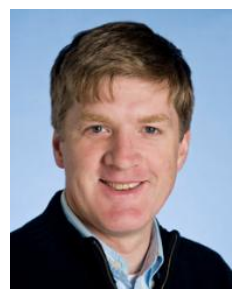

Stuart Pearson was born in Sydney Australia and as a geographer has explored Australian deserts, before travelling in Africa, USA and China. He has got the BA Hons, Dip Ed, and PhD degrees in UNSW in 1998. He has worked in government research investment and as an academic, most recently at the University of New South Wales (Canberra, Australia). He is working with excellent students on a variety of environmental management problems many related to policy and marine issues. Details are available http://pems.unsw.adfa.edu.au/staff/profiles/pearson/. Associate professor Stuart Pearson is a member of IAG and AQUA. 